PREGNANCY CARE FOR THE 1980s 


\title{
PREGNANCY CARE FOR THE 1980s
}

Based on a Conference Held at the Royal Society of Medicine

\author{
Edited by \\ LUKE ZANDER \\ Senior Lecturer, Department of General Practice \\ St Thomas's Hospital Medical School \\ London \\ and

\section{GEOFFREY CHAMBERLAIN} \\ Professor of Obstetrics and Gynaecology \\ St George's Hospital Medical School \\ London
}

\author{
Published jointly by \\ The Royal Society of Medicine \\ and
}

The Macmillan Press Ltd 
(C) The Royal Society of Medicine 1984

Softcover reprint of the hardcover 1st edition 1984

All rights reserved. No part of this publication may be reproduced or transmitted, in any form or by any means, without permission.

First published jointly in 1984 by

THE ROYAL SOCIETY OF MEDICINE

1 Wimpole St, London, W1

and

The Scientific and Medical Division

THE MACMILLAN PRESS LTD

London and Basingstoke

Companies and representatives throughout the world

ISBN 978-0-333-33346-4 ISBN 978-1-349-17389-1 (eBook)

DOI 10.1007/978-1-349-17389-1 


\section{The Contributors}

Professor Eva ALBERMAN

Dept of Clinical Epidemiology, The

London Hospital Medical College

Mrs Helen BENDER

Principal Child Psychotherapist, The London Hospital (Whitechapel)

Dr Michael J. V. BULL

General Practitioner, Oxford

Dr Iain CHALMERS

National Perinatal Epidemiology

Unit, Oxford

Professor Geoffrey CHAMBERLAIN

Dept of Obstetrics and Gynaecology,

St George's Hospital Medical School

Miss Valerie CHAPMAN

Senior Lecturer in Health Visiting, Polytechnic of the South Bank

Professor John DAVIS

Dept of Paediatrics, Cambridge University

Professor Sir John DEWHURST

Institute of Obstetrics, London

Dr Sue DOWLING

Dept of Community Health, University of Bristol

Dr Murray W. ENKIN

Dept of Obstetrics and Gynaecology, McMaster University, Hamilton, Ontario, Canada

Dr Marion H. HALL

Consultant Obstetrician and Gynaecologist, Aberdeen Teaching Hospitals

Miss Dora HENSCHEL

Principal of Midwifery Education, King's College Hospital, London

Dr Edmund N. HEY

Dept of Child Health, University of Newcastle upon Tyne

Ms Lea JAMIESON

West Hertfordshire School of Midwifery, Watford
Mrs Beryl KINGSTON

School Education Service

Mrs Sheila KITZINGER

Social Anthropologist, Oxford

Dr Michael KLEIN

Dept of Family Medicine, McGill University, Canada; Visiting Research Fellow, Dept of Obstetrics, Oxford

Professor G J KLOOSTERMAN

Professor and Chairman, Dept of Obstetrics and Gynaecology, University of Amsterdam

Mr Tom LEWIS,

President, RSM Section of Obstetrics and Gynaecology

Dr J. Aidan MACFARLANE

Community Paediatrician, Oxfordshire Health Authority

Dr Sally MACINTYRE

MRC Medical Sociology Unit, Aberdeen

Dr Ian H. MCKEE

General Practitioner, Edinburgh

Mrs Kate NEWSON

Senior Midwifery Tutor, St Mary's Hospital, London

Dr Ann OAKLEY

National Perinatal Epidemiology

Unit, Oxford

Dr Michel ODENT

Obstetrician, Pithiviers, Loiret, France

Dr Mia Kellmer PRINGLE (deceased)

Formerly Director, National Children's

Bureau

Mrs Gwenyth RANKIN

National Childbirth Trust, London

Dr Martin RICHARDS

Medical Psychology Unit, Cambridge

Dr Gordon W. TAYLOR

General Practitioner, Reading 
Professor R. W. TAYLOR

Dept of Obstetrics, St Thomas's Hospital, London

Mrs Marjorie TEW,

Statistician, Dept of Surgery, Medical

School, The University of Nottingham
Ms Juliet WILMOTT

Community Midwife, Islington Health District

Dr Luke ZANDER

Dept of General Practice, St Thomas's

Hospital, London 


\section{Contents}

The Contributors

Foreword Sir John Stallworthy

Preface

$\mathrm{v}$
$\mathrm{xi}$

xiii

SECTION I

ANTENATAL CARE

ARE OUR ACCEPTED PRACTICES BASED ON VALID ASSUMPTIONS?

Dr Marion H. Hall

2

CONSUMER REACTION TO PRESENT-DAY ANTENATAL SERVICES

Dr Sally Macintyre

3

THE PROVISION OF COMMUNITY ANTENATAL SERVICES

Dr Sue Dowling

COMMUNITY-BASED SPECIALIST OBSTETRIC SERVICES

Professor R. W. Taylor

5

COMMUNITY ANTENATAL CARE: THE SIGHTHILL COMMUNITY ANTENATAL

SCHEME

Dr Ian H. McKee

DISCUSSION

SECTION II

PARENT AND CHILD INTERACTION

THE MYTH OF BONDING

7

Dr Martin Richards

FACTS, BELIEFS AND MISCONCEPTIONS

ABOUT THE BONDING PROCESS

Dr J. Aidan MacFarlane

A PSYCHOTHERAPIST'S ROLE IN A SPECIAL

CARE BABY UNIT

Mrs Helen Bender

FAMILY-CENTRED OBSTETRICS

Dr Murray W. Enkin 
SECTION III INTRANATAL CARE-WITHIN THE HOME

STATISTICAL COMPARISON OF HOME AND HOSPITAL CONFINEMENTS

Professor Eva Alberman

UNDERSTANDING INTRANATAL CARE THROUGH MORTALITY STATISTICS

Mrs Marjorie Tew

THE DUTCH EXPERIENCE OF DOMICILIARY CONFINEMENTS

Professor G. J. Kloosterman

THE SIGNIFICANCE OF THE HOME DELIVERY ISSUE

Dr Luke Zander

THE COMMUNITY MIDWIFE AND DOMICILIARY CONFINEMENTS

Ms Juliet Wilmott

MODERN OBSTETRICS AND PATIENT CARE

Dr Michael J. V. Bull

WHAT ARE WE EXPECTING OF OUR MIDWIVES?

Miss Dora Henschel TITIONER AND SPECIALIST DELIVERY SERVICES

Dr M. Klein, I. Lloyd, C. Redman, M. Bull and A. C. Turnbull

EXPERIENCES OF OBSTETRIC PRACTICES IN DIFFERING COUNTRIES

Mrs Sheila Kitzinger 


\section{SECTION V}

PREPARATION FOR PARENTHOOD

A MEDICAL VIEW

Dr Edmund N. Hey

22

A MIDWIFE'S PERSPECTIVE

Ms Lea Jamieson

23

THE ROLE OF THE HEALTH VISITOR

226

Miss Valerie Chapman

24

THE PLACE OF THE NON-PROFESSIONAL EDUCATOR

Mrs Gwenyth Rankin

25

SCHOOL AGE IS THE TIME TO START

Mrs Beryl Kingston

DISCUSSION

SECTION VI

THE NEED FOR TODAY'S PLANNERS TO CONSIDER TOMORROW'S DEVELOPMENTS

WHICH WAY FORWARD FOR OBSTETRICS?

251

Professor Sir John Dewhurst

WHAT ARE WE TRAINING OUR GENERAL PRACTITIONERS FOR?

Dr Gordon W. Taylor

WHAT SORT OF MIDWIFERY SERVICE DO WE WANT?

Mrs Kate Newson

THE CONSUMER'S ROLE: ADVERSARY OR PARTNER?

Dr Ann Oakley 


\title{
Foreword
}

\author{
by
}

Sir John Stallworthy

One hundred and eighty years ago some doctors in London became concerned about the growing tendency to form multiple new medical and surgical societies within the city. This fragmentation was the more surprising at a time when scientific knowledge was relatively limited. Among those who reacted adversely to these divisive developments were men of vision who believed that medicine should be based on scientific principles, aided by access to, and use of, excellent libraries and good communications. The practical outcome of their concern was the amalgamation of a number of these groups into a new composite Medical and Chirugical Society with the nucleus of a splendid library. The Royal Society of Medicine developed from this metropolitan institution with national, and later international, membership and commitments.

The escalation of scientific progress with its many contributions to medicine and surgery revived interest in fragmentation into specialties and subspecialties with the creation of new colleges, faculties and other institutions. These have brought benefits to many aspects of patient care, but they have also increased those same dangers which worried our predecessors nearly two centuries ago. This medical revolution, for such it certainly is, has taken place while rapidly increasing knowledge, and the application of technological advances to medical and surgical practice have made acceptance of team concepts essential in the development and maintenance of high standards.

As a response to this changing scene, The Royal Society of Medicine has encouraged the creation of multidisciplinary forums designed to explore in depth subjects of importance to the profession and to society as a whole.

It is fitting that this publication should be edited by two such enthusiastic pioneers of the forum concept as Dr Luke Zander and Professor Geoffrey Chamberlain. The establishment of a forum entitled Maternity Care and the Newborn which followed directly from the pregnancy care conference owed much to their imaginative and careful planning, and marks a development for which many concerned with the provision of maternity care will, I believe, have cause to be grateful. Readers of this book will similarly be grateful to 
them for presenting a splendidly edited record of expert views from many differing disciplines and perspectives concerning an unusually wide range of aspects of pregnancy care. 


\section{Preface}

A disturbing characteristic of the contemporary medical scene is the steadily increasing fragmentation of the health care services. Owing in part to the inevitable increase in specialisation, contact and collaboration between individuals from different disciplines and specialty groups is becoming ever more difficult.

The developing isolation within which many are now working has important and significant implications to both the planning and delivery of medical care. The reduction in interdisciplinary communication, when important aspects of health care are under consideration, not only reduces the exchange of ideas, but also removes those checks and balances necessary to ensure that decisions taken from one perspective do not have unforeseen and perhaps damaging effects on other components of the overall system of health care.

Pregnancy care is a branch of medicine that has over the recent past become the focus of much debate and controversy in both medical and lay circles. It raises contentious issues concerning the objectives of care, the role of the consumer in decision making and how to ensure that the different professional groups concerned in maternity care can best make their appropriate contribution to overall patient management. Issues of this nature can only be considered satisfactorily in a multidisciplinary context.

The establishment of new Royal Colleges and many Subspecialty Groups have all had a significant effect on inhibiting interdisciplinary exchange, and at various times during the recent past the question has been raised as to the advisability and possibility of establishing an Academy or an Institute of medicine, to bring together individuals from the many branches of the profession.

The view has frequently been expressed that the Royal Society of Medicine, with its multidisciplinary composition, is particularly well suited to serve such a function, if certain changes in its way of working were to be undertaken. At present the clinical activities of the Society are largely derived from its specialty-orientated sections, but an important development which should greatly help it to realise its potential as a stimulus and catalyst for interdisciplinary debate is the prospective establishment of a number of topicrelated Forums, each concerned with a different aspect of health care. It is envisaged that these Forums will provide the means by which individuals from 
differing disciplines and perspectives will be enabled to come together in a setting independent of any sectarian vested interests to explore new ideas, unrestrained by the official protocol that all too frequently operates within institutions, such as the British Medical Association, the Royal Colleges and the Department of Health and Social Security.

As a preview to the establishment of the Pregnancy Forum, a conference entitled 'Pregnancy Care for the 1980s' was held at the Royal Society of Medicine in 1980. The participants came from many disciplines, which included obstetrics, general practice, paediatrics, midwifery, psychology, sociology and education, as well as representatives of the receivers of care. The aim of the meeting was to enable the participants to share views and ideas on the major and controversial issues concerning the management of pregnancy, rather than it being an occasion for the stating of established positions or the claiming of 'territories'. In producing this book of the proceedings, we have endeavoured to capture the sense of debate and interchange of views by including the essence of the discussions together with the formal papers, as these formed a very significant part of the conference.

The success of the meeting clearly underlined the value of such communication and illustrated the potential benefits to be derived from such gatherings. As conveners of the meeting we are very pleased that the Pregnancy Forum has subsequently been launched and is now firmly established at the Royal Society of Medicine.

\section{ACKNOWLEDGEMENTS}

We should like to express our very sincerest thanks to Miss Muriel Mitchell, the Conference Secretary of the Royal Society of Medicine, for the great amount of work she undertook to ensure the success of the meeting, and to Miss Judy Fagelston for her help in producing the transcript of the proceedings.

London, 1983

LIZ

GVPC 